\title{
Fascioliasis prevalence in livestock from abattoirs in southern Chile
}

\author{
Pamela Olivares-Ferrettia,b, Juan José Orellana-Cáceres ${ }^{\mathrm{c}}$, \\ Luis A. Salazard ${ }^{d}$ Flery Fonseca-Salamanca ${ }^{a, b *}$
}

\begin{abstract}
Fascioliasis is a widely distributed parasitic zoonosis caused by the trematode Fasciola hepatica that affects livestock production and generates high economic losses. In Chilean authorised abattoirs, the infected livestock livers are condemned during the veterinary inspection. This study aims to evaluate the prevalence of fascioliasis in Chile from 2014 to 2016 and also monthly from 2002 to 2015 in livestock (cattle, pig, sheep, horse and goat) slaughtered in abattoirs of La Araucanía region, southern Chile. To do this, the available records on abattoirs provided by the sanitary authority were analysed. A descriptive statistics and trend analysis of the data by jointpoint regression was carried out. The Biobío and La Araucanía regions registered the highest levels of parasitosis in the country recording levels of 59.18 and $44.74 \%$, respectively, and presented $50.03 \%$ of the liver condemnation rate in cattle. During the study period, a total of 2,239,164 animals were slaughtered and $40.59 \%$ infected livers with $F$. hepatica were condemned in the 9 existing abattoirs of La Araucanía region. The abattoirs located in the cities of Temuco (51.43\%) and Angol (65.09\%) recorded the highest percentages of fascioliasis. The cattle species recorded the highest number of slaughtered animals and liver condemnation $(54.52 \%)$. The presence of the parasite was recorded annually and monthly and it was possible to observe a slight increase in fascioliasis over the years. This study provides updated information on the fascioliasis prevalence in the country and the dynamics of condemnation in endemic areas such as La Araucanía region, which could contribute to the control and prevention of this zoonosis.
\end{abstract}

Key words: abattoir, Chile, fascioliasis, livestock.

\section{INTRODUCTION}

Fascioliasis is a zoonotic parasitic disease produced by Fasciola hepatica, a trematode of the Phylum Platyhelminthes globally distributed and found in every continent except Antarctica (Rojo-Vazquez and Ferre 1999). It seriously affects livestock, particularly sheep and cattle, impacting public health and causing significant productive and economic losses derived from the clinical picture and the condemnation of the liver (Mas-Coma et al 2009). The infection is caused by the intake of short-stemmed vegetation and waters contaminated with metacercariae of the parasite (Mas-Coma et al 2014). The World Health Organization defines human fascioliasis as a neglected reemerging tropical disease, with endemic and epidemic outbreaks throughout the world (WHO 2013). In cattle, the effects of this pathology in chronic stages are correlated with productivity, generating weight loss, reduced milk production and lower fleece quality (Schweizer et al 2005).

Received: 11.07.2021.

Accepted: 04.11.2021.

a'Laboratory of Molecular Immunoparasitology, Center of Excellence in Translational Medicine-Scientific and Technological Bioresource Nucleus (CEMT-BIOREN), Temuco, Chile.

${ }^{b}$ Preclinical Sciences Department, Faculty of Medicine, Universidad de La Frontera, Temuco, Chile.

'Public Health Department, Center of Training, Research and Management for Evidence-based Health (CIGES), Faculty of Medicine, Universidad de La Frontera, Temuco, Chile.

${ }^{\mathrm{d}}$ Center of Molecular Biology and Pharmacogenetics, Scientific and Technological Bioresource Nucleus (BIOREN), Universidad de La Frontera, Temuco, Chile.

*Corresponding author: F Fonseca-Salamanca; flery.fonseca@ufrontera.cl
In Chile, the disease is mainly associated with cattle and sheep. The most frequent production system involving these species is extensive grazing, which exposes the animal to various parasitic pathogens such as gastrointestinal nematodes and $F$. hepatica (Peña-Espinoza 2018).

The Chilean Agriculture and Livestock Service (SAG) regulates the slaughter of animals for consumption in authorised abattoirs. Through breeding protocols, prior examination and post-slaughter of productive species, SAG ensures the safety of slaughter livestock and their derivatives ${ }^{1}$, guaranteeing the organoleptic quality and preventing risks for the consumer. These practices are regulated by Law $\mathrm{N}^{\circ} 19.162$ of the Ministry of Agriculture ${ }^{2}$ and General Technical Standard $\mathrm{N}^{\circ} 62$ of the Ministry of Health ${ }^{1}$. During the veterinary inspection, transverse incisions are made into the liver to search for adults of $F$. hepatica or pathological lesions in the bile ducts. After detection, the condemned livers are classified as unfit for human consumption, generating a record that is kept by each abattoir ${ }^{1}$.

Currently, there is little updated research on the prevalence of $F$. hepatica or fascioliasis that provides information on the situation at both national and regional levels. This study aims to analyse the prevalence of the

Ministerio de Salud. 2009. Norma General Técnica N 62 Sobre inspección Medico-Veterinaria de reses y sus carnes. Biblioteca Del Congreso Nacional. Available at: https://www.leychile. $\mathrm{cl} / \mathrm{N} ? \mathrm{i}=1064158 \& \mathrm{f}=2009-09-14 \& \mathrm{p}=$

2 Ministerio de Agricultura. 1992. Ley 19.162, Sistema obligatorio de clasificación de ganado, tipificación y nomenclatura de sus carnes y regula funcionamiento de mataderos, frigoríficos y establecimientos de la industria de la carne. Biblioteca Del Congreso Nacional. Available at: https://www.leychile.cl/N?i=30529\&f=2009-07-03\&p= 
parasitosis through liver condemnation of infected livestock due to fascioliasis using the available SAG databases from authorised abattoirs, with information corresponding to Chile from 2014 to 2016 and the endemic region of $\mathrm{La}$ Araucanía during the period 2002-2015.

\section{MATERIAL AND METHODS}

The "Report on the Slaughtered Animals and Pathological Findings in National Abattoirs" was accessed, which contains the records of the main pathologies of interest to public health detected in slaughter animals from authorised abattoirs in Chile from 2014 to 2016. The Nuble region was included in the statistics of the Biobío region since the law for the creation of the first was promulgated in August 20173. Also, the "Statistics on SAG Abattoir Inspection" of La Araucanía region were accessed for the period 2002-2015.

The national registry is organised in two main sections: slaughtered animals (or animal gain) and pathological findings in abattoirs by year. The national and regional registry included the total number of animals by species and findings according to pathologies (echinococcosis, tuberculosis, fascioliasis, cysticercosis and trichinosis). The data corresponding to La Araucanía region was registered by month and year. The data did not include livestock traceability and the recordings are made at the end of the animal's life.

We recorded the number of both slaughtered animals and liver condemnations appearing in the national registry by region (Arica y Parinacota, Tarapacá, Coquimbo, Valparaíso, Metropolitana, O’Higgins, Maule, Biobío, La Araucanía, Los Ríos, Los Lagos, Aysén and Magallanes regions) and productive species (cattle, pig, sheep, horse and goat). The data of La Araucanía was organised by year, month and nine authorised abattoirs, with the productive livestock being grouped into the five categories previously mentioned. La Araucanía region is one of Chile's 16 administrative divisions, located at the coordinates $38^{\circ} 54^{\prime} \mathrm{S}$ $72^{\circ} 40^{\prime} \mathrm{W}$. The studied abattoirs were Frigorífico Temuco S.A. (Temuco), Faenadora de Carnes Angol (Angol), Faenadora de Carnes Victoria S.A. (Victoria), Comercial Frigosur Rio Toltén Ltda. (Pitrufquén), Sociedad Faenadora y Comercializadora de Productos Alimenticios Araneda Ltda. (Imperial), Sociedad Matadero Chol Chol Ltda. (Chol Chol) and Matadero Industrial Lautaro (Lautaro). Also included were the abattoirs located in Galvarino and Hualpín which ceased functions in October 2005 and December 2006, respectively.

3 Ministerio del Interior y Seguridad Pública. 2017. Ley 21.033, Crea la XVI región de Nuble y las provincias de Diguillín, Punilla e Itata. Biblioteca Del Congreso Nacional. https://www.leychile. $\mathrm{cl} / \mathrm{N} ? \mathrm{i}=1107597 \& \mathrm{f}=2018-09-06 \& \mathrm{p}=$

\section{STATISTICAL ANALYSIS}

The database was elaborated using a Microsoft Excel worksheet and exported to STATA15 software (StataCorp LLC, College Station, Texas, U.S.A.) for statistical analysis. The basic statistical analysis included the estimation of prevalence and mean of the prevalence over time. The trend analysis of the prevalence through time was done using a Joinpoint Regression (Kim et al 2000) and the Trend Analysis Software of the $\mathrm{NIH}^{4}$. The graphs were obtained using the GraphPad Prism version 7.00 software (GraphPad Software, La Jolla, California U.S.A.).

\section{RESULTS AND DISCUSSION}

The annual record of the statistics and trends of the most commonly detected pathologies in abattoirs at national level allowed us to perform passive monitoring to support the sanitary and zoonotic management in the country. In all the regions with authorised abattoirs of the country, $F$. hepatica was found in livers of productive animals in authorised abattoirs during the years 2014-2016.

In the early 1990s, the distribution and trend of fascioliasis in Chilean abattoirs was $30.1 \%$ for cattle (Morales and Luengo 2000). There is a great variation in the prevalence recorded in Latin America where countries such as Brazil, with industrial livestock, report numbers of $18.6 \%$ for the state of Rio Grande do Sul and $24.9 \%$ for the state of Espíritu Santo, with $7.32 \%$ being recorded between 2002 and 2011 nationwide (Molento et al 2018). In Uruguay, parasitosis exceeds $50 \%$ prevalence in productive farms (Sanchís et al 2015) while in Mexico, where human fascioliasis is significant (Mas-Coma et al 2014), condemnation in abattoirs due to $F$. hepatica reaches 20.99\% (Rangel and Martínez 1994). On the other hand, Costa Rica has low prevalence levels $(1.82 \%)$ of adults of F. hepatica after veterinary inspection (Rojas and Cartín 2016). Likewise, in the state of Lara, Venezuela, $8.49 \%$ of the animals slaughtered in abattoirs were reported as fascioliasis findings (Quijada et al 2005). Despite the differences existing within the Latin American meat industry, during the last decade, $F$. hepatica consistently appeared in those countries.

There are few reports of the prevalence of the parasite in Chile, including human fascioliasis case reports (López et al 2004, Morales et al 2009, Rosas et al 2008, Venturelli et al 2003) and a case report on resistance to triclabendazole treatment in the Metropolitana region (Gil et al 2014). Fascioliasis, as a problem of veterinary concern, is mainly absent from the epidemiological and public health context, with only one report on the prevalence in endemic areas during the late 1980s (Apt et al 1993). The livestock is

\footnotetext{
4 National Institutes of Health. Division of Cancer Control \& Population Sciences. USA. 2000. Joinpoint Trend Analysis Software. Available at: https://surveillance.cancer.gov/joinpoint/
} 
mainly concentrated in the centre and south of the country where the main productive activity is located. It has been given special attention as an endemic area for the parasite (Apt et al 1993).

The prevalences (SD) obtained in our study raise the alert for the significant presence of the parasite in the country. The abattoirs located in Biobío 59.18 (4.32) \% and La Araucanía regions 44.74 (2.87) \%, (figure 1) stand out due to a prevalence similar to that reported in Zambia $(64.4 \%)$ where the animals exhibit poor body condition (Nyirenda et al 2019). The percentage of condemned livers reaches the highest levels in endemic areas of human fascioliasis, particularly in the department of Apurimac (80.1\%) in Perú (Espinoza et al 2010). Also, abattoirs in other regions of Chile reported a significant presence of the parasite with Los Ríos and Los Lagos regions presenting condemnations of 26.27 (1.39) \% and 26.11 (2.57) \%, respectively (figure 1).

Our results show a higher prevalence in the southern regions of the country, particularly in the Biobío, La Araucanía, Los Ríos and Los Lagos regions. The elevated livestock population of the area is an important factor that influences the prevalence. Moreover, it is well known that climate conditions and climate changes can affect the parasitism of the species (Hughes 2000). In the case of $F$. hepatica, this impact is conditioned by the freshwater snail, an intermediate host that determines the possibility of completing the life cycle of this zoonotic disease (Reinhard 1957) due to its sensitivity to temperature and soil moisture (Yigezu et al 2018). The weather in southern Chile is temperate humid, with rainfall throughout the year. The feeding systems used in the southern regions are predominantly extensive and mixed, where the grazing behaviour of the livestock allows the exposure to the infective stages of $F$. hepatica (Fox et al 2013), unlike the case of more intensive systems used in Metropolitana $24.91(4.10) \%$, O'Higgins $0.22(0.02) \%$ and Maule 6.80 (0.56) \% regions. The conditions related to the prevalence are shown in figure 1.

The collected data was obtained from the authorised abattoirs at the end of the productive life of the animals. Therefore, the analysis does not consider livestock traceability making impossible to determine where the animals getting infected are or their movement between regions. Further studies that include traceability are needed to enrich the investigation.

The national record displays a total of 20,005,649 animals slaughtered during the study period, with the liver condemnation rate (SD) in cattle being 50.03 (1.56) \% nationwide (figure 2). Previous reports in the early 1990 s showed a lower prevalence of $30.1 \%$ for the species (Morales and Luengo 2000). The second most infected productive species was equine with 18.3 (1.59) \% where the parasitosis was similar to previous reports on fascioliasis in equines. Morales et al (2009) reported $12.3 \%$, a similar study found $13.54 \%$ (Apt et al 1993 ) and a recent work described $10.4 \%$ in racehorses (Muñoz et al 2008). In the other species, our results showed that goats reach $1.29(1.35) \%$ as opposed to the findings of Morales and Luengo (2000) with 14\%. The least parasitised livestock species were ovines and porcines with $0.28(0.05) \%$ and $0.01(0.01) \%$ respectively, corresponding with a downward trend of this species as reported in previous works (Morales and Luengo 2000), but in disagreement with the $20.61 \%$ reported by Apt et al (1993). In cattle and equine species, the prevalence observed is related to previous reports but an increase in prevalence is observed.

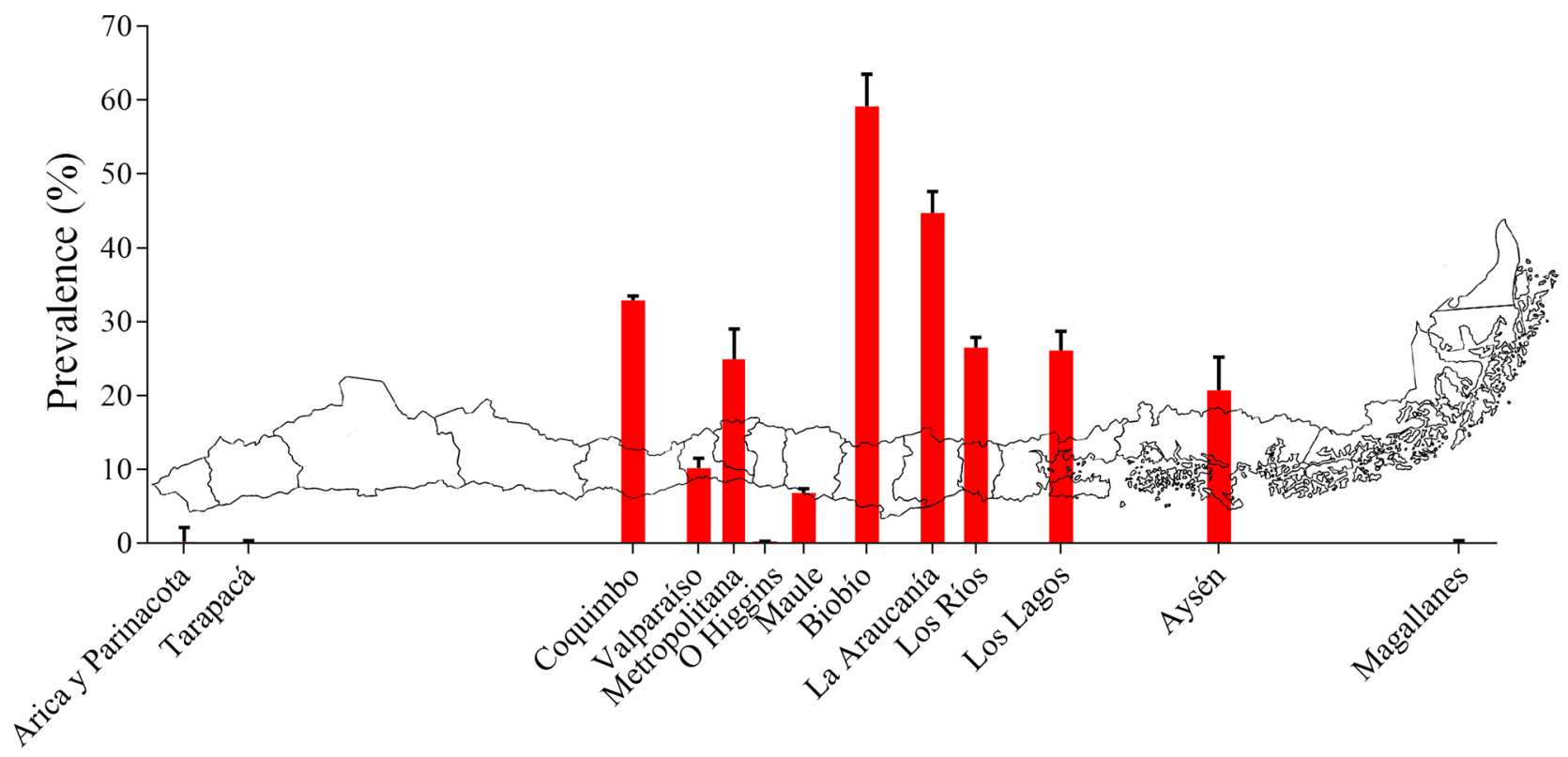

Figure 1. Prevalence of fascioliasis (\% red) in Chile abattoirs, during the period 2014-2016. Standard deviation (T) is displayed. 


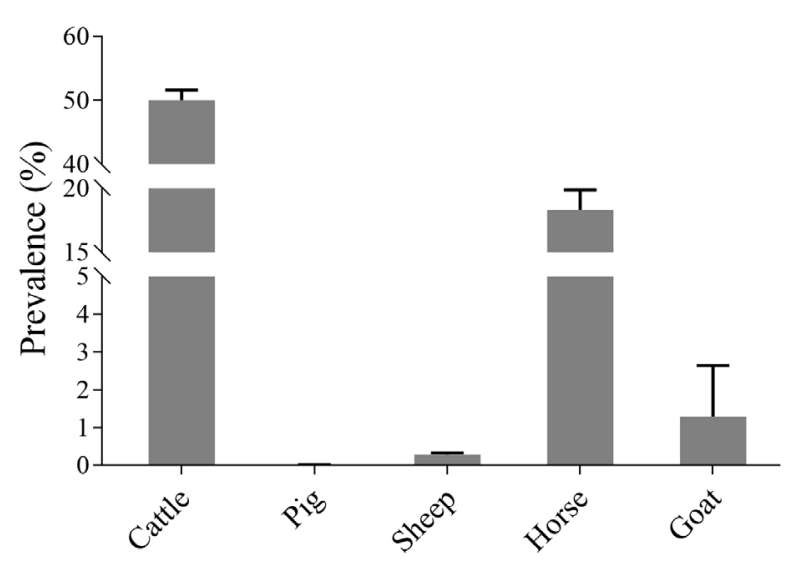

Figure 2. Prevalence of fascioliasis in main productive species slaughtered in Chile abattoirs from 2014 to 2016. Standard deviation ( $\mathrm{T}$ ) is displayed.

Between 2002 and 2015, a total of 2,239,164 animals were slaughtered in La Araucanía region, reporting condemnations of $40.59 \%$ due to F. hepatica $(908,901$ animals with findings) (see supplementary material 1). The highest levels of fascioliasis correspond to the abattoirs located in Angol and Temuco (65.09 and 51.43\%, respectively) (figure 3). Microclimates are crucial for the distribution of vectors, this particularly concerns diseases transmitted by water-borne vectors such as freshwater snails (Mas-Coma et al 1999). The increase in winter temperatures raise the metabolic rate, egg production and feeding frequency of invertebrates (De La Rocque et al 2008). The Angol borough has mediterranean climate with mild temperatures and rainy winters and its weather is warmer than in other boroughs of the central valley in the same region, where the abattoirs of Temuco, Victoria (32.49\%), Lautaro (3.33\%) and Pitrufquén $(9.51 \%)$ are located (figure 3). This microclimate would explain the prevalence exhibited by the Angol abattoir, considering

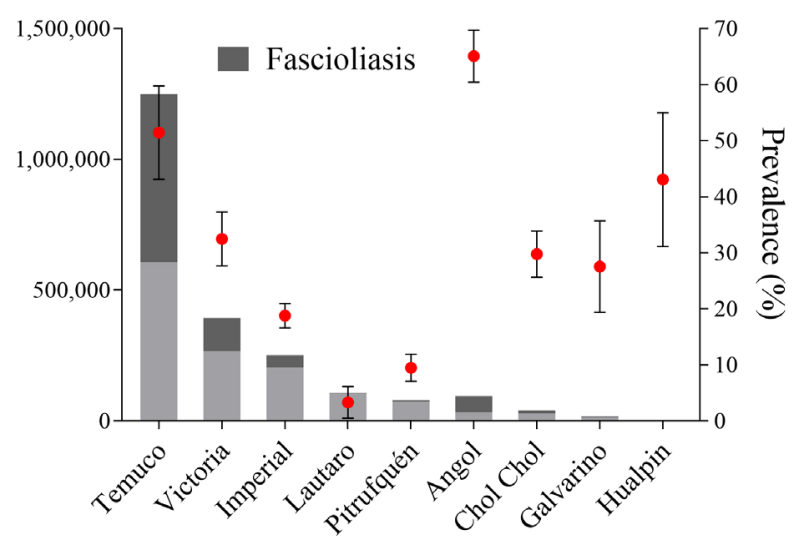

Figure 3. Number of slaughtered animals (columns) and fascioliasis (dark grey), prevalence of fascioliasis (\%) (red) and 95\% confidence interval $(\mathrm{T})$ by abattoir in La Araucanía region, during the period 2002-2015. that it recorded only 95,571 slaughtered animals during the studied period.

The rural boroughs of Galvarino and Hualpín range within the lowest quintile of the percentage of the population living with poverty income (Ministerio de Desarrollo Social 2015 ) and in less than 5 years of operation it registered a high level of condemnation due to $F$. hepatica, recording 27.56 and $43.09 \%$, respectively (figure 3 ). The uptime of abattoirs and missing data were recorded (see supplementary material 2). La Araucanía is the region with the lowest economic income up to 2017 (Ministerio de Desarrollo Social 2017) with a rural population of $29.1 \%$ which is higher than the national average (INE 2017). These factors contribute negatively to control this or any parasitosis, harming livestock and health management. The use of an extensive system and veranadas ${ }^{5}$ conditions animal movement to agroecological areas with greater vegetable mass and annual precipitation (Catrileo 2015), propitiating the distribution and seasonality of the intermediary host (Mas-Coma et al 2009). Those conditions allow permanent infection in the areas used for grazing, being associated with the prevalence exhibited.

The dynamic behaviour shows an increase in the number of cattle associated with the increasing demand for the product in the national reports (Cofré 2019, INE 2019), with a marked difference between 2007 (138,978 total animals) and 2008 (191,072 total animals). Our results exhibit three periods, only the first period between 2002 and 2007, characterised by high prevalence indices, was statistically significant $(P=0.0048)$ with an annual percent change of 21.7 , reaching $60.09 \%$ in 2007 , the highest record of condemnations for the period studied. The two periods between 2008 and 2015 were not significant, recording $45.19 \%$ in condemnations in 2015 (figure 4). This behaviour is probably due to the modification made to the regulation on the veterinary inspection of cattle and their meats, General Technical Standard $\mathrm{N}^{\circ} 62^{1}$, which was promulgated in July 2002 and entered into force in 2009. The main modification was the certification by SAGaccredited professionals of the control and monitoring of cattle and their derivatives, reforming the requirements of the abattoirs. Therefore, the impact on livestock production and the control of infectious diseases by producers and government services resulted in the improvement of sanitary programs for cattle.

According to our results, slaughter increased the most in December (225,710 total of animals) which is linked to an increase in consumption due to the end of the year celebrations (Cofré 2019). Studies have suggested that the prevalence of $F$. hepatica is conditioned by the ecology of its intermediary host and aquatic vector, a lymnaeid of the genus Galba (Artigas et al 2011). Considering its habitat

Yáñez Barrios L. 2018. Región de la Araucanía, Información regional. Oficina de Estudios y Políticas Agrarias, 16. Available at: www. odepa.gob.cl 


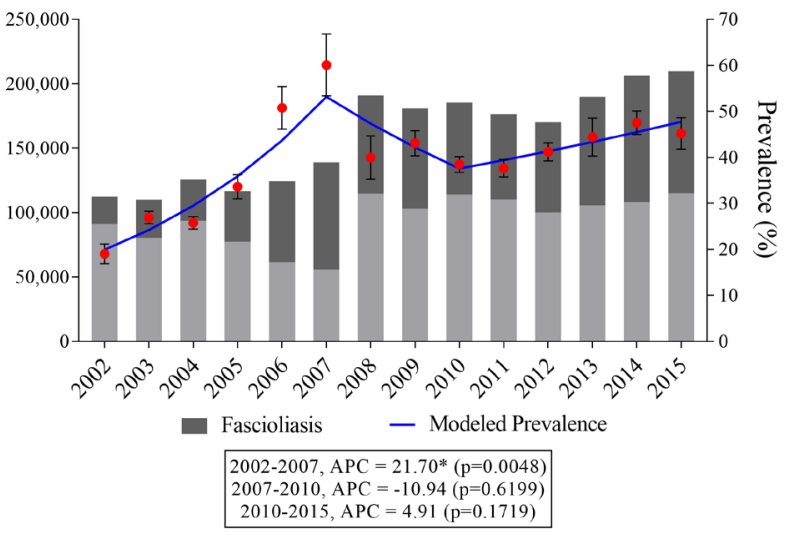

Figure 4. Number of slaughtered animals (columns) and fascioliasis (dark grey), prevalence of fascioliasis (\%) (red), 95\% confidence interval over time ( $\mathrm{T}$ ) and modeled prevalence (blue), during the period 2002-2015 in La Araucanía region. *Indicates that the Annual Percent Change (APC) is significantly greater than zero (Jointpoint regression).

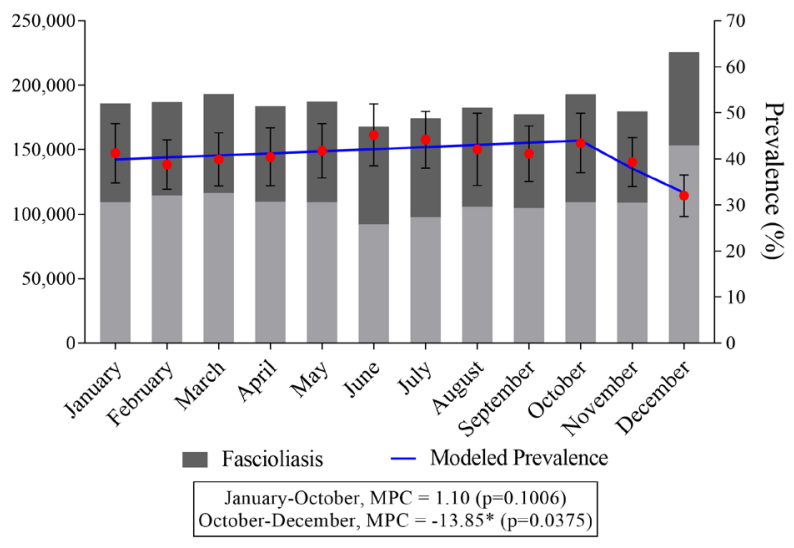

Figure 5. Number of slaughtered animals (columns) and fascioliasis (dark grey), prevalence of fascioliasis (\%) (red), 95\% confidence interval over time ( $\mathrm{T}$ ) and modeled prevalence (blue), by month in La Araucanía region, during the period 2002-2015. *Indicates that the Monthly Percent Change (MPC) is significantly smaller than zero (Jointpoint regression).

and the climatic conditions of the area, the increase in precipitation and temperature would in turn increase the snail populations (Müller et al 1999). Our results show that during the rainy season in the Southern Hemisphere, June (45.20\%), July (44.15\%) and August (42.09\%), there was a lower intake number and high numbers of condemnations (figure 5). This is related with prevalence reports during ideal seasons for their development, in countries such as Venezuela (Quijada et al 2005), China (Yuan et al 2016), Vietnam (Nguyen and Nguyen 2012) and Cuba (Palacio Collado et al 2017), suggesting an even higher probability of becoming infected in the rainy season (Byrne et al 2018, Novobilský et al 2014). However, the change in monthly percentage through this period was not significant. On the other hand, the prevalence between the spring months - November and December - shows a statistically significant $(P=0.0375)$ lower index $(39.32$ and $32.00 \%$, each) (figure 5), probably associated with preventive deworming which takes place at the beginning of the spring as part of government programs. It is important to emphasise the permanent indices throughout the year. The half-life of $F$. hepatica has been reported to be more than two years in livestock (Mas-Coma et al 2014); the constant elimination of eggs from the definitive host (Robles-Pérez et al 2015) and the invariable presence of the intermediary host in the area (Mas-Coma et al 1999) causes constant reinfection.

The most relevant among the productive species was cattle which registered findings of fascioliasis in the abattoirs of Temuco (51.43\%) and Victoria (32.49\%). The importance of cattle species and the parasitic prevalence of $F$. hepatica had been previously reported at national level (Morales and Luengo 2000). Smaller productive species such as pigs, sheep and goats are traditionally home slaughtered for private consumption although it is an illegal activity without health certification ${ }^{2}$ that is not included in official abattoir records.

The prevalence observed is related to the definitive host tolerance to the infection (Rojo-Vazquez and Ferre 1999). The greatest percentage was reported in cattle (54.52\%) because it exhibited low receptivity and delay in response to the implantation process in the liver (Boray 1999, Boray et al 1969). In more receptive mammals, such as goat (4.84\%) and sheep (4.68\%), there is a high parasitic activity and noticeable pathogenicity, producing acute symptoms that in most cases are lethal (Boray 1999, Boray 1985). On the other hand, we recorded low prevalence in pig $(0.39 \%)$ and horse $(3.65 \%)$ which confirms that they respond more quickly to hepatic invasion (figure 6) (Boray et al 1969).

In conclusion, fascioliasis is the main cause of condemnation in slaughtered livestock at national and regional levels, with cattle reporting the highest prevalence.

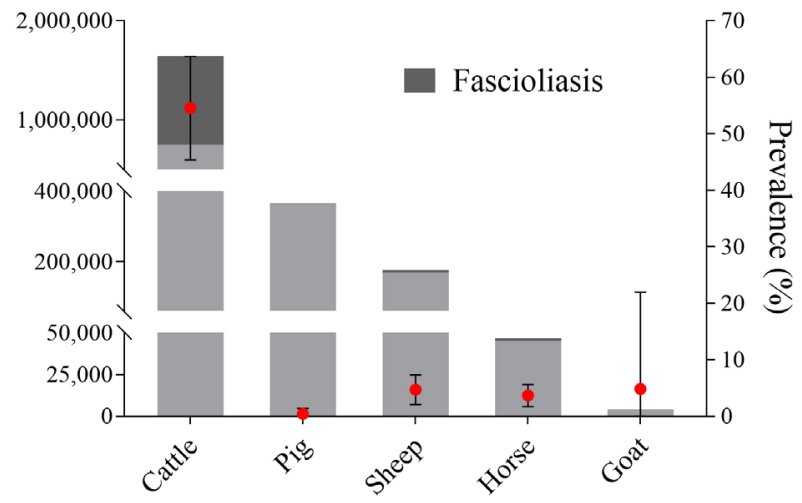

Figure 6. Number of slaughtered animals (columns) and fascioliasis (dark grey), prevalence of fascioliasis (\%) (red) and $95 \%$ confidence interval $(\mathrm{T})$ by main productive species in $\mathrm{La}$ Araucanía region, during the period 2002-2015. 
The weather as well the productive system are associated with the prevalence found between the centre and the south regions of the country. The Biobío and La Araucanía regions show the highest rates in Chile and, in particular, $\mathrm{La}$ Araucanía region presents a high prevalence of $F$. hepatica. The presence of the intermediary host favoured by the climatic conditions of the area ensures the cycle of the parasite, reporting constant prevalence with a low variation during the chronological year. The dynamic behaviour of the parasitosis reports a slight increase in the prevalence through the years studied. Our results indicate a constant and evident prevalence of the parasite to the detriment of the productive economy and the organoleptic quality of the product due to the inflammatory process. The analysis of condemnation records at national and regional levels is a representative methodology to determine prevalence and monitoring of the disease and is useful for the epidemiological control and management of $F$. hepatica.

\section{ACKNOWLEDGEMENTS}

P.O.F. is grateful for the support of ANID scholarship $N^{\circ} 2017$ 21170159.

\section{REFERENCES}

Apt W, Aguilera X, Vega F, Alcaíno H, Zulantay I, et al. 1993. Prevalencia de fascioliasis en humanos, caballos, cerdos y conejos silvestres, en tres provincias de Chile. Boletin de La Oficina Sanitaria Panamericana 115, 405-414.

Artigas P, Bargues MD, Mera RL, Agramunt VH. 2011. Characterisation of fascioliasis lymnaeid intermediate hosts from Chile by DNA sequencing, with emphasis on Lymnaea viator and Galba truncatula. Acta Tropica 120, 245-257.

Boray J. 1985. Fluke of domestic animals. In: Graafat SM, Howard WE, Marsh RE (eds). Parasites and Predators. Elsevier; New York, USA, Pp 179-185.

Boray J. 1999. Liver fluke disease in sheep and cattle. AGFACTS NSW Agriculture 1-16.

Boray J, Happich FA, Andrews JC. 1969. The epidemiology of Fasciolosis in two representative endemic regions of Australia. Aust Vet J 45, 549-553.

Byrne AW, Graham J, McConville J, Milne G, McDowell S, et al. 2018. Seasonal variation of Fasciola hepatica antibodies in dairy herds in Northern Ireland measured by bulk tank milk ELISA. Parasitol Res 117, 2725-2733.

Catrileo A. 2015. Decisiones de manejo en producción de carne bovina. Boletín INIA 316. Temuco, Chile.

Cofré CR. 2019. Comportamiento y caracterización de la producción de ganado bovino en Chile. INE, Santiago, Chile.

De La Rocque S, Rioux JA, Slingenbergh J. 2008. Climate change: effects on animal disease systems and implications for surveillance and control. Rev Sci Tech 27 339-354.

Espinoza JR, Terashima A, Herrera-Velit P, Marcos LA. 2010. Fasciolosis humana y animal en el Perú: Impacto en la economía de las zonas endémicas. Revista Peruana de Medicina Experimental y Salud Pública 4, 604-612.

Fox NJ, Marion G, Davidson RS, White PCL, Hutchings MR. 2013. Modelling parasite transmission in a grazing system: The importance of host behaviour and immunity. PLOS ONE 8.

Gil LC, Díaz A, Rueda C, Martínez C, Castillo D, et al. 2014. Fascioliasis hepática humana: Resistencia al tratamiento con triclabendazol. Revista Med Chile 142, 1330-1333.
Hughes L. 2000. Biological consequences of global warming: is the signal already apparent? Trends Ecol Evol 15, 56-61.

INE, Instituto Nacional de Estadísticas. 2017. Memoria CENSO 2017. Instituto Nacional de Estadística, Santiago, Chile.

INE, Instituto Nacional de Estadísticas. 2019. Ferias y mataderos, trimestre enero-marzo 2019. Instituto Nacional de Estadística 6, 6-8.

Kim H, Fay MP, Feuer E J, Midthune DN. 2000. Permutation test for joinpoint regression with applications to cancer rates. 351, 335-351.

López A, Silva C, Busel D. 2004. Fasciolasis hepática: Reporte de un caso y revisión de la literatura. Revista Chilena de Radiología 10, 118-123.

Mas-Coma S, Anglés R, Esteban JG, Bargues MD, Buchon P, et al. 1999. The Northern Bolivian Altiplano: A region highly endemic for human fascioliasis. Trop Med Int Health 4, 454-467.

Mas-Coma S, Valero MA, Bargues MD. 2009. Climate change effects on trematodiases, with emphasis on zoonotic fascioliasis and schistosomiasis. Vet Parasitol 163, 264-280.

Mas-Coma S, Valero MA, Bargues MD. 2009. Chapter 2 Fasciola, Lymnaeids and Human Fascioliasis, with a Global Overview on Disease Transmission, Epidemiology, Evolutionary Genetics, Molecular Epidemiology and Control. Adv Parasit 69, 41-146.

Mas-Coma S, Valero MA, Bargues MD. 2014. Fascioliasis. In: Toledo R, Fried B (eds). Digenetic Trematodes. Springer, New Yor, USA, Pp 77-114.

Ministerio de Desarrollo Social. 2015. Informe de Desarrollo Social CASEN, La Araucanía. Encuesta de Caracterización Socioeconómica Nacional. Ministerio de Desarrollo Social, Santiago, Chile.

Ministerio de Desarrollo Social. 2017. Informe de Desarrollo Social CASEN Nacional. Encuesta de Caracterización Socioeconómica Nacional. Ministerio de Desarrollo Social, Santiago, Chile.

Molento MB, Bennema S, Bertot J, Pritsch IC. 2018. Bovine fascioliasis in Brazil : Economic impact and forecasting. Veterinary Parasitology: Regional Studies and Reports 12, 1-3.

Morales MA, Luengo J. 2000. Distribución y tendencia de la fasciolosis en ganado de abasto en Chile. Parasitología Al Día 24, 9-11.

Morales GJL, Arriagada HR, Salas GL, Morales AC, Fuentes AF, et al. 2009. Hematoma subcapsular por Fasciolasis. Revista Chilena de Cirugía 61, 73-77.

Müller G, Berne M, Raffi L, Jesus L, Paulsen R, et al. 1999. Influences of temperature on longevity of metacercarie of Fasciola hepatica. Revista Brasileira de Agrociencia 5, 164-165.

Muñoz L, Rubilar L, Zamora D, Sepúlveda O, Rehhof C, et al. 2008. Fasciolosis en equinos fina sangre de carrera del Club Hípico Concepción, Chile. Parasitología Latinoamericana 63, 88-91.

Nguyen ST, Nguyen DT. 2012. Prevalence of Fasciola in cattle and of its intermediate host Lymnaea snails in central Vietnam. Trop Anim Health Pro, 1847-1853.

Novobilský A, Engström A, Sollenberg S, Gustafsson K, Morrison DA, et al. 2014. Transmission patterns of Fasciola hepatica to ruminants in sweden. Vet Parasitol 203, 276-286.

Nyirenda SS, Sakala M, Moonde L, Kayesa E, Fandamu P, et al. 2019. Prevalence of bovine fascioliasis and economic impact associated with liver condemnation in abattoirs in Mongu district of Zambia. BMC Vet Res 15, 1-8.

Palacio Collado D, Bertot Valdés JA, Beltrao Molento M, Vázquez Gil Á, Izquierdo Pérez N, et al. 2017. Comportamiento estacional de Fasciola hepatica en bovinos sacrificados en el matadero Chacuba, Camagüey, Cuba. Revista de Producción Animal 29, 30-35.

Peña-Espinoza M. 2018. Drug resistance in parasitic helminths of veterinary importance in Chile: Status review and research needs. Austral J Vet Sci 50, 65-76.

Quijada T, Araque C, Jimenez M, Pacheco A, Quijada J, et al. 2005. Prevalencia de la Fasciola hepática en bovinos en un matadero Industrial del estado de Lara. Venezuela. Gaceta de Ciencias Veterinarias 10

Rangel JL, Martínez E. 1994. Pérdidas por decomiso de hígados y distribución geográfica de la fasciolosis bovina en el estado de Tabasco, México. Vet Mex 25, 327-331. 
Reinhard EG. 1957. Landmarks of parasitology I. The discovery of the life cycle of the liver fluke. Exp Parasitol 6, 208-232.

Robles-Pérez D, Martínez-Pérez JM, Rojo-Vázquez FA. 2015. Screening anthelmintic resistance to triclabendazole in Fasciola hepatica isolated from sheep by means of an egg hatch assay. BMC Vet Res 1-5.

Rojas D, Cartín JA. 2016. Prevalencia de Fasciola hepatica y pérdidas económicas asociadas al decomiso de hígados en tres mataderos de clase a de Costa Rica. Agron Costarric 40, 53-62.

Rojo-Vazquez FA, Ferre P. 1999. Parasitosis hepáticas, Fasciolosis. In: Cordero del Campillo M, Rojo-Vazquez FA (eds). Parasitología Veterinaria. McGraw-Hill Interamericana, Madrid, España, Pp 260-272.

Rosas LH, Fiestas FC, Torres MR, Aita CG, Lozada MD. 2008. Hematoma subcapsular hepatico por fasciolasis. Revista Chilena de Radiologia 14, 20-24.

Sanchís J, Hillyer GV, Madeira De Carvalho LM, Macchi MI, et al. 2015. Riesgo de exposición a Fasciola hepatica en ganado vacuno en extensivo de Uruguay y Portugal determinado mediante ELISA y un antígeno recombinante. Arch Med Vet 47, 201-208.
Schweizer G, Braun U, Deplazes P, Torgerson PR. 2005. Estimating the financial losses due to bovine fasciolosis in Switzerland. Vet Rec 157, 188-193.

Venturelli LA, Monje KM, Assef PV, Venturelli MF. 2003. Fasciolasis hepática. Cuadernos de Cirugía 17, 43-46.

WHO, World Health Organization. 2013. Sustaining the drive to overcome the global impact of neglected tropical diseases: second WHO report on neglected tropical diseases. Geneva, Switzerland.

Yáñez Barrios L. 2018. Región de la Araucanía, Información regional. Oficina de Estudios y Políticas Agrarias, 16. www.odepa.gob.cl

Yigezu G, Mandefro B, Mengesha Y, Yewhalaw D, Beyene A, et al. 2018. Habitat suitability modelling for predicting potential habitats of freshwater snail intermediate hosts in Omo-Gibe river basin, Southwest Ethiopia. Ecol Inform 45, 70-80.

Yuan W, Liu J, Lu K, Li H, Duan M, et al. 2016. Molecular identification and seasonal infections of species of Fasciola in ruminants from two provinces in China. J Helminthol 359-363. 
